\title{
Dragon Fruit Foliage Plant-Based Coagulant for Treatment of Concentrated Latex Effluent: Comparison of Treatment with Ferric Sulfate
}

\author{
Juferi Idris, ${ }^{1}$ Ayub Md Som, ${ }^{2}$ Mohibah Musa, ${ }^{2}$ Ku Halim Ku Hamid, \\ Rafidah Husen, ${ }^{3}$ and Miradatul Najwa Muhd Rodhi ${ }^{2}$ \\ ${ }^{1}$ Faculty of Chemical Engineering, Universiti Teknologi MARA, Sarawak Campus, 94300 Kota Samarahan, Sarawak, Malaysia \\ ${ }^{2}$ Faculty of Chemical Engineering, Universiti Teknologi MARA, 40450 Shah Alam, Selangor, Sarawak, Malaysia \\ ${ }^{3}$ Faculty of Applied Sciences, Universiti Teknologi MARA, Sarawak Campus, 94300 Kota Samarahan, Sarawak, Malaysia
}

Correspondence should be addressed to Juferi Idris; juferi@sarawak.uitm.edu.my

Received 24 May 2012; Revised 13 September 2012; Accepted 13 September 2012

Academic Editor: Darren Sun

Copyright (C) 2013 Juferi Idris et al. This is an open access article distributed under the Creative Commons Attribution License, which permits unrestricted use, distribution, and reproduction in any medium, provided the original work is properly cited.

\begin{abstract}
The effectiveness of dragon fruit foliage as a natural coagulant for treatment of concentrated latex effluent was investigated and compared with ferric sulfate, a chemical coagulant. Dragon fruit is a round and often red-colored fruit with scales-like texture and is native to south American countries which is also cultivated and heavily marketed in southeast Asian countries. Its foliage represents a part of its overall plant system. Latex effluent is one of the main byproduct from rubber processing factories in Malaysia. Three main parameters investigated were chemical oxygen demand (COD), suspended solids (SS), and turbidity of effluent. Coagulation experiments using jar test were performed with a flocculation system where the effects of latex effluent $\mathrm{pH}$ as well as coagulation dosage on coagulation effectiveness were examined. The highest recorded COD, SS, and turbidity removal percentages for foliage were observed for effluent $\mathrm{pH} 10$ at $94.7,88.9$, and $99.7 \%$, respectively. It is concluded that the foliage showed tremendous potential as a natural coagulant for water treatment purposes. The foliage could be used in the pretreatment stage of Malaysian latex effluent prior to secondary treatment.
\end{abstract}

\section{Introduction}

The Malaysian natural rubber industry has become among the most important agriculture-based industries in this country. Currently, Malaysia is the third largest natural rubber (NR) producer in the world [1] with total productions of natural rubber in 2011 of 996,210 tonnes for both dry and latex amounted to almost RM 13,278 million [2]. Malaysia rubber industry's contribution to national exports from natural rubber, rubber products, hevea wood products, and other rubber in 2011 amounted RM40.42 billion equivalent to $5.82 \%$ of Malaysia's export [3]. Meanwhile, world rubber production and consumption in 2011 were 26,089,000 tonnes and 25,850,000 tonnes, respectively [4]. However, the effluents generated from this industry create a major impact on the natural environment. It is estimated that in average, 20 tonnes of rubber and 410 thousand litres of effluent per day are produced by rubber factory and some reported 80 million litres of untreated rubber effluent are discharged daily into streams and rivers from the rubber processing factories in Malaysia [1, 5-7]. Untreated latex concentrate effluent comprises a large quantity of water for washing and cleaning of raw materials, small amount of uncoagulated latex, and serum (protein, carbohydrate, lipid, carotenoids, and salt) [1] . Highly contaminated with serum contributed to high BOD (Table 1), therefore this effluent when discharged into water course will deplete dissolved oxygen present in the water and eventually affect aquatic life.

Biological treatments such as pond technology and aerobic and anaerobic methods are the most commonly used treatment systems. However, these treatment systems come with large area requirement, high maintenance, long retention time, and high emission hydrogen sulfide $\left(\mathrm{H}_{2} \mathrm{~S}\right)$ which causes malodour problems associated with treatment 
TABLE 1: The characteristics of concentrated latex effluent [1,5-13] and regulatory discharge standard limits [14].

\begin{tabular}{lccc}
\hline Parameters & \multicolumn{2}{c}{$\begin{array}{c}\text { Concentrated latex } \\
\text { effluent }(\mathrm{mg} / \mathrm{L})\end{array}$} & \multicolumn{2}{c}{ Regulatory standard discharge limit (mg/L) } & B \\
\hline $\mathrm{pH}$ & $3.7-5.5$ & $6.0-9.0$ & $5.5-9.0$ \\
Biochemical oxygen demand (BOD) & $1500-7000$ & 20 & 50 \\
Chemical oxygen demand (COD) & $3500-14000$ & - & 100 \\
Total solid (TS) & 7576 & 50 & - \\
Suspended solid (SS) & $200-700$ & - & - \\
Total nitrogen & $200-1800$ & - & - \\
Sulfate & $500-2000$ & & - \\
\hline
\end{tabular}

All values except for $\mathrm{pH}$ are expressed in $\mathrm{mg} / \mathrm{L}$.

of concentrated latex effluent using pond systems [1]. It is of high time to identify the best coagulant for coagulation processes in order to ensure the final discharge is well-treated.

Coagulation is an important process in the treatment of both surface water and industrial wastewater. Its application includes removal of dissolved chemical species and turbidity via addition of chemical-based coagulants such as alum $\left(\mathrm{AlCl}_{3}\right)$, ferric chloride $\left(\mathrm{FeCl}_{3}\right)$, and polyaluminium chloride (PAC). While the effectiveness of these chemicals as coagulants are well-established $[15,16]$, there are, nonetheless, disadvantages associated with the usage of these coagulants such as relatively high procurement costs as well as detrimental effects on human health and environment. It is therefore desirable that these chemical coagulants are replaced with cost-effective natural coagulants to counteract the aforementioned disadvantages.

To date, a variety of natural substances such as bone shell extracts, bark resins, and natural mineral soils have been examined for their coagulation properties [17]. Research on natural coagulants from plant-based material has been focused on Moringa oleifera [18-21] for the past two decades but more researchers are studying application of other natural plant coagulants such as cactus Latifaria and Opuntia. It is reported that cactus Latifaria has the potential for use as a natural water treatment coagulant [22] while cactus Opuntia exhibits high turbidity removal efficiency for sewage and seawater treatment [23]. Opuntia spp. operates predominantly through a bridging coagulation mechanism and represents a part of point-of-use water treatment technology for producing portable water in developing communities [24]. A recent study indicates that Opuntia ficus-indica grows in arid and semiarid regions of Mexico and other countries produces "mucilage" that contains polygalacturonic acid (biopolymer) with interesting coagulating-flocculating capabilities with $65 \%$ of the initial COD being removed at pH 10 (dose of $50 \mathrm{mg} / \mathrm{L})$ [25].

According to Pichler et al. [26], mucilage derived from the species Opuntia ficusindica demonstrated high efficiency of the cactus to eliminate turbidity compared to aluminium sulfate $\left(\mathrm{Al}_{2}\left(\mathrm{SO}_{4}\right)_{3}\right)$. The mucilage extract increased particulatesettling rates $330 \%$ compared with aluminium sulfate, at dosage concentration of $3 \mathrm{mg} / \mathrm{L}$, while its performance was equivalent at doses $0.3 \%$ of the required $\mathrm{Al}_{2}\left(\mathrm{SO}_{4}\right)_{3}$ concentration. Hence, the positive outcome of studies on cactus-based wastewater coagulation justifies further research on other natural coagulants.

Coming from the family Cactaceae, dragon fruit of Hylocereus genus or also known as pitaya is a round, juicy, and highly nutritious fruit. It is often red-colored with scaleslike texture and is native to Mexico, central and south America [27]. It is also cultivated and heavily marketed in southeast Asian countries where the fruit is highly favorable. It is well established as a new crop in Australia, China, Israel, Malaysia, Nicaragua, Taiwan, and Vietnam [28]. The commercial production of dragon fruit in Israel, Malaysia, and Taiwan produces $16000-27000 \mathrm{~kg} / \mathrm{ha}$ [29]. The foliage of the plant represents a part of its overall system. It can be found abundantly but of no particular usage. In commercial production of the fruits, proper foliage thinning is important in achieving a good fruit size and yield [30].

We hypothesized that dragon fruit foliage can also be used for a similar purpose as cactus Latifaria and Opuntia. In our opinion, usage of natural coagulant directly contributes to the global sustainable technology initiatives since the dragon fruit plant is relatively abundant, innocuous, and biodegradable. On the basis of the above discussion, the main objective of this study is to investigate the effectiveness of dragon fruit foliage as a natural coagulant for treatment of concentrated latex effluent. Latex effluent is one of the main byproducts from rubber processing factories in Malaysia which comprises mainly of carbonaceous organic materials, nitrogen, and sulfate [31]. The three main parameters investigated were chemical oxygen demand (COD), suspended solids (SS), and turbidity of effluent. The coagulation effectiveness of the foliage is compared with ferric sulfate, a chemical coagulant.

\section{Experimental}

Samples of concentrated latex effluent were obtained from MARDEX Industrial Latex in Perak, Malaysia. The effluent was collected from the process line prior to chemical flocculation and sedimentation unit operations within the plant. The samples' collection and storing were based on standard method for the examination of water and wastewater [32]. $\mathrm{pH}$ value and temperature of latex effluent were determined using a portable $\mathrm{pH}$ meter ( $\mathrm{HACH}$ model). Raw concentrated latex effluent is a white-colored suspension at average $\mathrm{pH}$ of 7.3 and mainly consists of water. 
2.1. Preparation of Dragon Fruit Foliage. Dragon fruit foliage was collected from Tanjung Malim smallholder in Perak, Malaysia. Its thorns were removed and the foliage was subsequently washed, cut, and dried at $80^{\circ} \mathrm{C}$. It was blended into fine powder and sieved to a particle size range of $0.45-1.25 \mathrm{~mm}$.

2.2. Preparation of Ferric Sulfate. Ferric sulfate was purchased from chemical company in Subang, Malaysia, in powder form with approximately $97 \%$ purity. Ferric sulfate solution was prepared by $51.5 \mathrm{~g}$ ferric sulfate dissolved in $1000 \mathrm{~mL}, 5 \%$ (v/v) distilled water solution. The solution was well stirred for jas test analysis.

2.3. Coagulation Jar Test Experiments. Coagulation experiments using jar test were performed in laboratory with a Bioblock flocculation that comprises six-paddle rotor $(24.5 \mathrm{~mm} \times 63.5 \mathrm{~mm})$ for $500 \mathrm{~mL}$ high shaped beakers which is in accordance to standards [32] and all tests were conducted at room temperature. The Jar test coagulation experiment using dragon fruit foliage and ferric sulfate was conducted separately. $500 \mathrm{~mL}$ of latex concentrate effluent was poured into each of the 6 beakers. The desired amount of coagulant was added to the suspension and stirred at rapid mixing (120 rpm) for 1 minute. The mixing time and speed were recorded. The speed of stirrer was reduced to slow mixing (30 rpm) for 20 minutes to keep flocs particles uniformly suspended. The paddles were then withdrawn and settling of flocs particles was observed and recorded. The mixture was left for 1 hour and then the supernatant was collected to be used in the determination of the COD, SS, and turbidity using the standard method. The effect of $\mathrm{pH}$ was studied in the range of 2-11 and the effect of dosage was studied in the range from $200 \mathrm{mg} / \mathrm{L}$ to $800 \mathrm{mg} / \mathrm{L}$. All analyses were done in triplicates and $\mathrm{pH}$ of wastewater samples was controlled by adding $1.0 \mathrm{M} \mathrm{H}_{2} \mathrm{SO}_{4}$ or $1.0 \mathrm{M} \mathrm{NaOH}$.

2.4. Analytical Analysis. Turbidity test was performed using HACH Model 2100P portable turbidimeter with measurement in nephelometric turbidity unit (NTU). This turbidimeter can measure turbidity from 0.001 to $1000 \mathrm{NTU}$ in automatic range mode with automatic decimal point. The measurement is based on the light-transmitting properties of water. Suspended solid was carried out with the aid of vacuum filtration apparatus. The initial weight of filter paper was recorded after drying in the oven at $100^{\circ} \mathrm{C}-105^{\circ} \mathrm{C}$ for 1 hour. A $10 \mathrm{~mL}$ of the water sample was filtered through a glass fibre filter. The residue was dried to constant weight at $100^{\circ} \mathrm{C}-105^{\circ} \mathrm{C}$ for 1 hour. The filter paper was then cooled in dessicator before weighing. The total suspended solid content was calculated by using equation below:

$$
\text { Suspended Solid } \approx \frac{A-B}{C} \times 10^{6},
$$

where $A$ is weight of disk + remaining solids (g), $B$ is weight of empty disk $(\mathrm{g})$, and $C$ is volume of sample $(\mathrm{mL})$.

The COD test was performed according to $\mathrm{HACH}$ reactor digestion procedure, colorimetric determination method
8000 using DR $2000 \mathrm{HACH}$ spectrophotometer with the COD range from 200 to $15,000 \mathrm{mg} / \mathrm{L}$. Since the COD value of latex concentrated effluent was more than $1000 \mathrm{mg} / \mathrm{L}$, high range (HR) COD digestion reagent was used with the concentrated latex effluent sample. Two COD digestion reagents were used for both the sample and the blank test. The COD reactor was first preheated at $150^{\circ} \mathrm{C}$ followed by placing $2 \mathrm{~mL}$ of wastewater sample into the vials using volumetric pipettes and deionized water was used to replaced wastewater sample for blank test. The mixtures were mixed and then placed in the preheated COD reactor for 2 hours. The reactor was then turned off and left idle for about 20 minutes prior to cooling to $120^{\circ} \mathrm{C}$ or less. Colorimetric determination was then read at 435 COD HR modes.

The BOD experiment was carried out using respirometric method (HACH method 10099). It was measured at $20^{\circ} \mathrm{C}$ under 5-day incubation. The $20^{\circ} \mathrm{C}$ wastewater sample of a known range and volume was poured into a BOD track sample bottle. BOD nutrient buffer pillow was added for optimum bacteria growth. Lithium hydroxide powder pillow was also added and stirred. The bottle was placed at the BOD track apparatus inside the incubator at temperature of $20^{\circ} \mathrm{C}$. The BOD results were taken after 5-day incubation.

The value of sulfate was performed using DR 2400 spectrophotometer. $10 \mathrm{~mL}$ of treated wastewater was added into the sample cell while deionized water was used for reference. Sulfate Ver 4 reagent powder pillow was also added, stirred, and then left for 5 minutes for reaction to take place.

The value of ammonia-nitrogen was determined using DR 2400 spectrophotometer. $0.1 \mathrm{~mL}$ of treated wastewater was added into ammonia-nitrogen reagent while deionized water was used for reference. Ammonia salicylate reagent powder pillow and ammonia cyanurate reagent powder pillow were added into each vial and mixed thoroughly. Both vials were left for 20 minutes for the reaction to take place.

Carbon $(\mathrm{C})$, Hydrogen $(\mathrm{H})$, and Nitrogen $(\mathrm{N})$ contents in dragon fruit foliage were determined using the $\mathrm{CHNS} / \mathrm{O}$ Analyzer (LECO CHNS932, USA). Approximately $2000 \mathrm{mg}$ of very fine cut of oven dried dragon fruit foliage were placed in a tin capsule and crimped. Three types of crimped capsules were analyzed; placed in the auto sampler for the CHNS/O analyzer Sulfamethazine, and dragon fruit foliage sample and blank as standard. The temperature of the analyzer oxidation was set at $1000^{\circ} \mathrm{C}$. A program run the analysis automatically and the results were given in percentage.

Malvern Zetasizer 3000 was used to measure zeta potential of dragon fruit foliage coagulant. Experiments were performed at coagulant dosage of $0.01 \mathrm{~mol} / \mathrm{L}$ as $\mathrm{Fe}$ and $\mathrm{pH}$ of the coagulant solutions was adjusted by adding HCL $(1 \mathrm{~mol} / \mathrm{L})$ or $\mathrm{NaOH}(1 \mathrm{~mol} / \mathrm{L})$. After 5 minutes of gentle stirring, the samples were analyzed and the data were recorded.

\section{Results and Discussion}

3.1. Characteristics of Raw Concentrated Latex Effluent. Table 2 shows the characteristics of concentrated latex effluent before the coagulation pretreatment. The values were within the range based on previous result $[1,5-13]$ except for 
TABLE 2: Values of selected parameters of raw concentrated latex effluent.

\begin{tabular}{lc}
\hline Parameters & $\begin{array}{c}\text { Raw concentrated } \\
\text { latex effluent }\end{array}$ \\
\hline $\mathrm{pH}$ & 7.3 \\
$\begin{array}{l}\text { Biochemical oxygen demand }\left(\mathrm{BOD}_{5}\right) \\
\text { at } 20^{\circ} \mathrm{C}\end{array}$ & $1527 \mathrm{mg} / \mathrm{L}$ \\
Chemical oxygen demand & $7857 \mathrm{mg} / \mathrm{L}$ \\
Suspended solids & $1208 \mathrm{mg} / \mathrm{L}$ \\
Sulfate & $1290 \mathrm{mg} / \mathrm{L}$ \\
Ammoniacal nitrogen & $101 \mathrm{mg} / \mathrm{L}$ \\
Turbidity & $7243 \mathrm{NTU}$ \\
\hline
\end{tabular}

$\mathrm{pH}$ and SS. This was due to the large amount of water used in factory operation and this can be shown by the $\mathrm{pH}$ at average of 7.3 during sampling. It is obvious that treatment of the effluent is required before it can be discharged into the environment since the COD concentration alone is more than 70 times higher than discharge limit. Further analysis indicated that the $\mathrm{BOD} / \mathrm{COD}$ ratio is approximately 0.17 implying low biodegradability and difficulty for natural attenuation in the environment.

3.2. Characterization of Dragon Fruit Foliage. Elemental analysis (Table 3) was conducted to provide a comparison between the elemental compositions of the foliage and that of other natural coagulants, Moringa oleifera, and cactus Opuntia. In this study, it was determined that the foliage contained $43.1 \% \mathrm{C}, 3.8 \% \mathrm{~N}$, and $2.9 \% \mathrm{H}$.

To investigate the reason of high efficiency and the latex concentrate treatment mechanism of dragon fruit foliage coagulant, the variation of zeta potential hydrolysis products as a function of $\mathrm{pH}$ was measured. In this series of experiments, the $\mathrm{pH}$ value was varied by addition of $\mathrm{HCL}$ or $\mathrm{NaOH}$ solution. It needs to be pointed out that the $\mathrm{pH}$ values in zeta experiments were the same as the $\mathrm{pH}$ of coagulant solution $(0.5 \mathrm{~g} / \mathrm{L})$. In this study, the working solution was the distilled water. The data obtained were summarized in Figure 1. Zeta potential is a controlling parameter of charge neutralization of coagulant and can usually be used to interpret the trend of coagulation efficiency. The zeta potential of dragon fruit foliage coagulant decreased from 32.2 to $15.8 \mathrm{mV}$ as the $\mathrm{pH}$ was increased from 4.5 to 7.5 . The value of the zeta potential is practically constant in wide range of $\mathrm{pH}$ (from 4 to 8). The latex concentrate in water has a negative charge on its surface, so the higher the positive charge on the coagulant surface, the higher the latex concentrate removal efficiency.

A standard jar test is an important procedure to help select the most appropriate coagulant for a particular effluent treatment. It allows individual polymer to be evaluated based on criteria such as floc formation, settling characteristics, and clarity of treated effluent. Figure 2 shows the floccules before and after the coagulation process of concentrated latex effluent using light microscope. Denser and larger floccules clearly appeared after the coagulation process using dragon

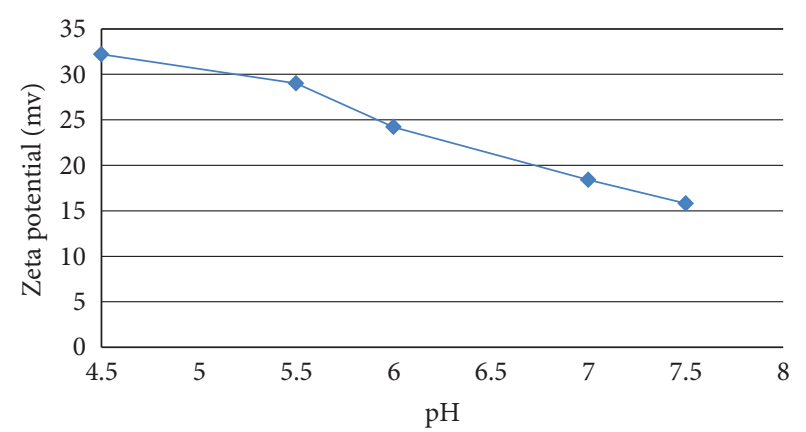

FIGURE 1: Variations of the zeta potential with respect to $\mathrm{pH}$ for dragon fruit foliage coagulant.

fruit foliage. This is an early indication of the coagulative capability of the foliage.

3.3. Effect of Effluent pH on Coagulation Effectiveness. $\mathrm{pH}$ of the solution during coagulation affects the chemistry of the coagulant. For example, ferric salts undergo rapid, uncontrolled hydrolysis reactions upon their addition to water, forming a series of chemical products or complexes [33]. Therefore, it is important to determine the influence of controlled latex effluent $\mathrm{pH}$ on coagulation effectiveness. Figure 3 shows the effect of latex effluent $\mathrm{pH}$ on coagulation effectiveness at coagulant dosage of $500 \mathrm{mg} / \mathrm{L}$. Generally, the COD, SS, and turbidity removal percentages for ferric sulfate are higher than foliage at corresponding effluent $\mathrm{pH}$. The highest recorded COD, SS, and turbidity removal percentages for foliage were observed for effluent $\mathrm{pH} 10$ at 94.7, 88.9, and $99.7 \%$, respectively. Ferric sulfate exhibits consistent COD, SS, and turbidity removal within the $\mathrm{pH}$ range of 3-10 in which percentage COD removal exceeded $90 \%$.

The curve for foliage is rather different compared to ferric sulfate in which there were two discernible "peak" values at $\mathrm{pH} 3$ and 10 for the former. Nonetheless, it can be argued that these two "peak" values also existed for the ferric sulfate COD curve albeit, they were not as apparent as the foliage curve. A similar observation is seen from the findings by Zhang et al. [23] where the lowest turbidity removal percentages recorded using cactus Opuntia are at pH 6 and 7 while the optimum $\mathrm{pH}$ is 10 . It is interesting to note that this two "peak" pH phenomenon is not exclusive to this study (or natural coagulant) but also observed in other coagulation studies as well. Findings from Aziz et al. [34] on color removal from landfill leachate using ferric sulfate indicate a similar trend in which the two "peak" pH values are 4 and 12 with lower colour removal percentages at $\mathrm{pH} 6$ and 7. In their findings, these two "peak" $\mathrm{pH}$ values are far more discernible compared to our ferric sulfate study most probably due to chemicals present in latex effluent which are more amenable to the formation of flocs and not so much so for chemicals in landfill leachate. We suggest that the relatively lower removal percentages at effluent $\mathrm{pH}$ around 7 for foliage as well as observed in the aforesaid studies are caused by solution neutrality as opposed to acidic and basic $\mathrm{pH}$ where the elevated concentration of either $\mathrm{H}^{+}$or $\mathrm{OH}^{-}$causes more electrostatic interactions between the coagulant and chemical species in the effluent and thus promotes coagulation. 
TABLE 3: Elemental analysis of dragon fruit foliage and comparison with other natural coagulants.

\begin{tabular}{lcccc}
\hline Parameters & Shelled Moringa seeds [35] & Nonshelled Moringa seeds [35] & Cactus Opuntia [36] & Dragon fruit foliage \\
\hline C (\%) & 54.8 & 53.3 & 29.4 & 43.1 \\
N (\%) & 6.1 & 5.0 & 2.3 & 3.8 \\
H (\%) & 8.5 & 7.7 & 1.7 & 2.9 \\
\hline
\end{tabular}

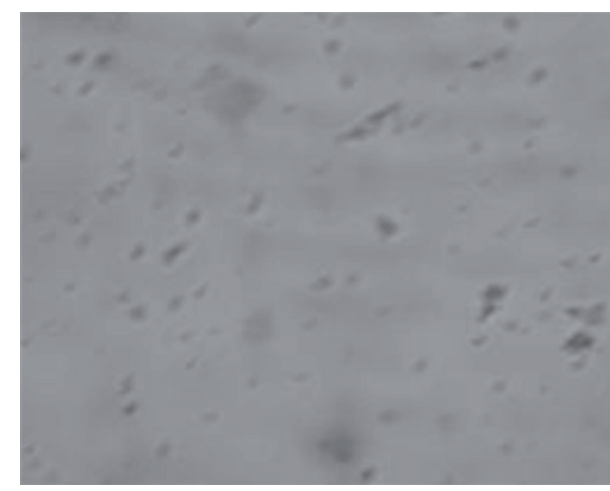

(a)

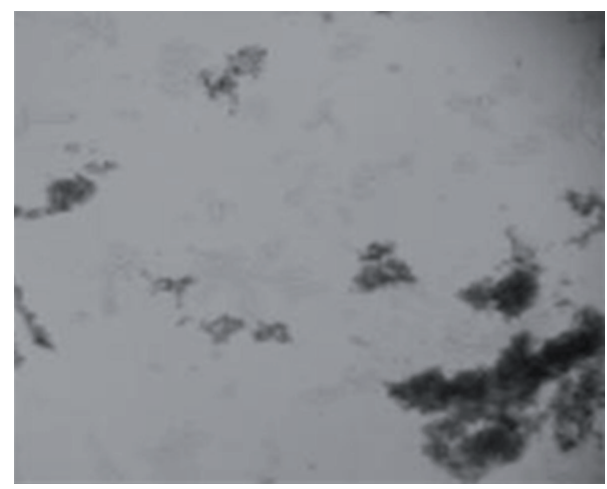

(b)

FIGURE 2: Floccules (a) before and (b) after the coagulation process of concentrated latex effluent.

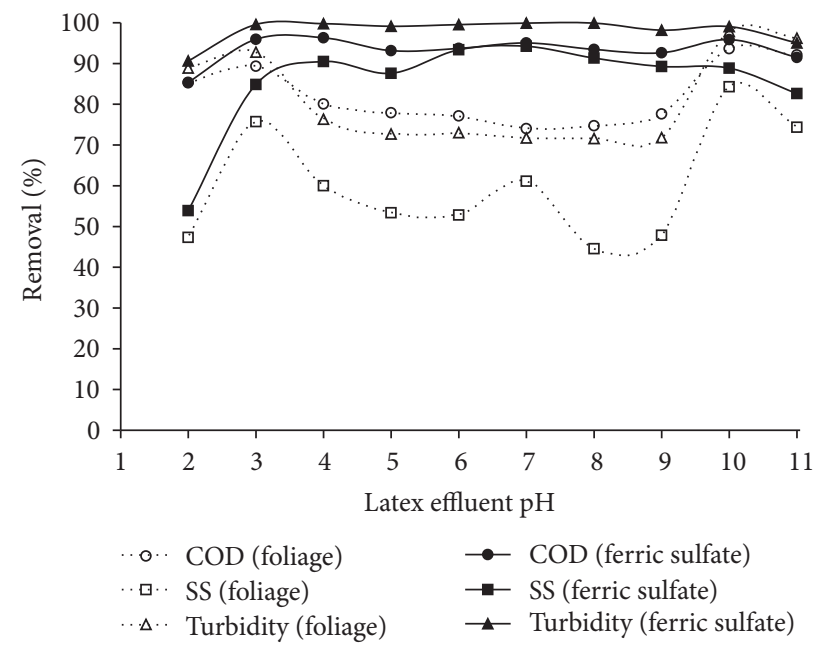

FIGURE 3: Effect of latex effluent $\mathrm{pH}$ on coagulation effectiveness at coagulant dosage $500 \mathrm{mg} / \mathrm{L}$.

3.4. Effect of Coagulant Dosage on Coagulation Effectiveness. Figure 4 shows the effect of coagulant dosage on coagulation effectiveness at optimum $\mathrm{pH}$ values of 10 and 7 for foliage and ferric sulphate, respectively. These $\mathrm{pH}$ values were selected based on our previous findings in this study. For ferric sulfate dosage range of $250-750 \mathrm{mg} / \mathrm{L}, \mathrm{COD}$ and turbidity removal percentages showed marginal difference in which more than $98 \%$ removal was achieved. Similarly, foliage dosage range of $200-800 \mathrm{mg} / \mathrm{L}$ showed consistent removal of COD and turbidity (>95\%). It appeared that SS removal percentages were consistently lower than that of COD and turbidity for both coagulants. It was rather obvious that both coagulants showed high removal percentages $(>88 \%)$ for all the investigated parameters even though it could be argued

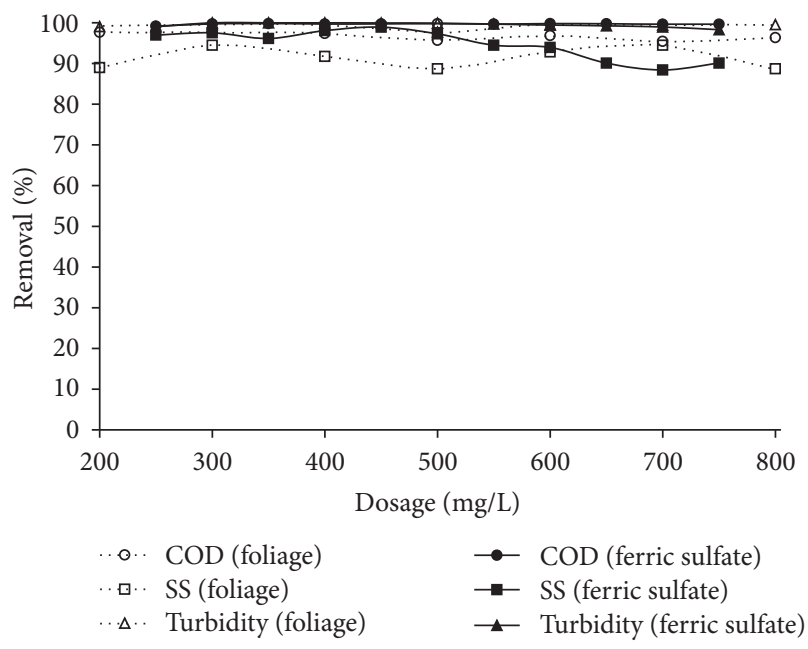

Figure 4: Effect of coagulant dosage on coagulation effectiveness at optimum effluent $\mathrm{pH}$.

that the foliage showed marginally lower COD removal percentages (>95\%) compared to ferric sulfate (>99\%). The use of natural coagulants may increase the organic load in waters [37] resulting in the possibility for undesired and increased microbial activity [24]. As such, this factor may be partly responsible for the foliage not achieving COD removal percentage as high as exhibited by ferric sulfate. This is because increased microbial activity increases BOD concentration and subsequently contributes to increased COD concentration in an aqueous solution.

3.5. Comparison with Malaysian Standard Effluent Discharge Limit. A crucial aspect of industrial wastewater treatment is to reduce contaminants concentrations of point-source 
effluent discharge to within regulatory permissible limits. As such, it is of interest to evaluate the extend of effectiveness of foliage in reducing the COD and SS concentrations of the latex effluent with respect to regulatory effluent discharge limit, so that suitability of the foliage as a pretreatment or allinclusive coagulant can be determined.

Figure 5 analyzes the compliance of COD and SS concentrations of treated latex effluent (at optimum $\mathrm{pH}$ ) with standard effluent discharge limits A and B stipulated by the DOE, Malaysia. Ferric sulfate is capable of reducing both the COD and SS concentrations to lower than Standard A limit $(50 \mathrm{mg} / \mathrm{L})$ at a dosage range of $300-500 \mathrm{mg} / \mathrm{L}$. This indicates that the ferric sulfate can be used as an all-inclusive coagulant for treating Malaysia latex effluent produced by a rubber processing plant located downstream of a water supply intake point, though this aspect is greatly dependent on the initial COD concentration of the effluent (which should be lower than $7800 \mathrm{mg} / \mathrm{L}$ to be applicable).

For foliage, SS concentrations of treated effluent fluctuated around Standard B limit $(100 \mathrm{mg} / \mathrm{L})$ while its corresponding $\mathrm{COD}$ concentrations were clearly higher than Standard A and B for all dosages. Nonetheless, it is erroneous to construe from this observation that the foliage is an ineffective or unsuitable coagulant for latex effluent since the foliage is capable of removing more than $88 \%$ of COD concentrations as proven in previous sections. Therefore, by considering the two aspects of removal percentages as well as regulatory compliance, it can be surmised that the foliage can be used in the pretreatment stage of Malaysian latex effluent prior to secondary treatment. From this study, it can be implied that dragon fruit foliage shows tremendous potential as natural coagulant for water treatment purposes. COD removal percentages of more than $88 \%$ are rather impressive as the latex effluent contains an amalgamation of organic and inorganic substrates which normally complicate coagulation treatment. We suggest that the foliage may even exhibit higher contaminant removal percentages for less complex or solute concentrated waters such as surface water (rivers and lakes).

\section{Conclusion}

Generally, the COD, SS, and turbidity removal percentages for ferric sulfate were higher than foliage at corresponding effluent $\mathrm{pH}$. However, this was not a true indication of the relative coagulative effectiveness of the foliage. The lower removal percentages for foliage were probably due to increased organic load from biological components of foliage and subsequently contributed to increased BOD and COD concentrations in the solution media. The highest recorded COD, SS, and turbidity removal percentages for foliage were observed for effluent $\mathrm{pH} 10$ at 94.7, 88.9, and 99.7\%, respectively, which were rather impressive considering the complex chemical nature of the latex effluent. As such, it could be concluded that the foliage showed tremendous potential as natural coagulant for water treatment purposes. For this study, since the foliage showed high COD removal percentages and yet could not reduce the COD concentrations to less than Standard B limit, it is suggested that it could be used in the pretreatment stage of Malaysian latex

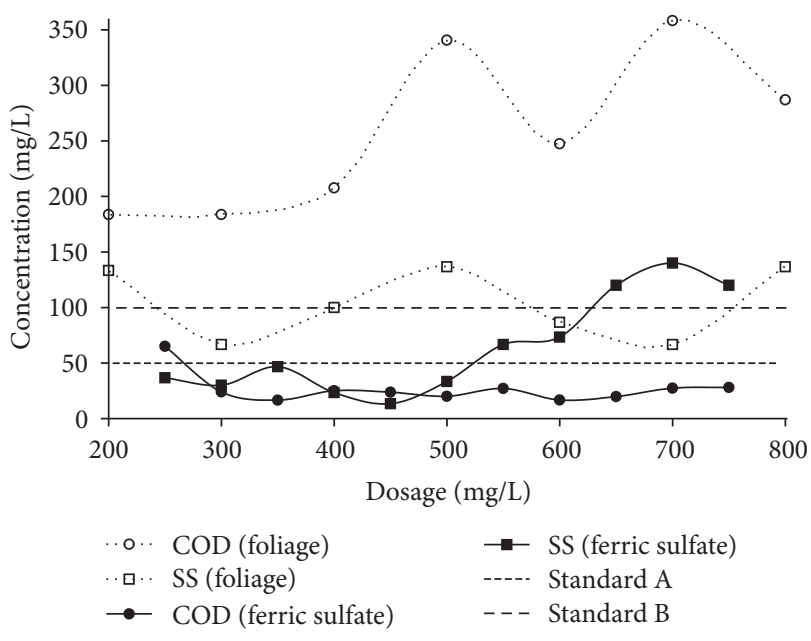

FIgURE 5: Comparison analysis of COD and SS concentrations of treated latex effluent (at optimum $\mathrm{pH}$ of 10 for foliage and 7 for ferric sulfate) with standard effluent discharge limits A and B stipulated by the Department of the Environment, Malaysia [14]. Initial COD and SS concentrations were 7857 and 1208, respectively.

effluent prior to secondary treatment. For future study, it is recommended that the dragon fruit foliage be used for other wastewater treatments.

\section{Acknowledgments}

The authors gratefully acknowledge the Research Management Institute (RMI), Universiti Teknologi MARA, for providing research grant for this study, Universiti Teknologi MARA, Sarawak Campus for facilities, and technical support and management of MARDEX Industrial Latex Sdn Bhd for providing the latex effluent samples.

\section{References}

[1] M. Mohammadi, H. C. Man, M. A. Hassan, and P. L. Yee, "Treatment of wastewater from rubber industry in Malaysia," African Journal of Biotechnology, vol. 9, no. 38, pp. 6233-6243, 2010.

[2] Departmentof Statistics, Malaysia, "Natural Rubber statistics 2011," Malaysia Rubber Board, 2011, http://www.lgm.gov.my/ nrstat/nrstats.pdf.

[3] Department of Statistics, Malaysia and Malaysian Timber Industry Board (MTIB), "Natural Rubber statistics 2011," Malaysia Rubber Board, 2011, http://www.lgm.gov.my/nrstat/ nrstats.pdf.

[4] International Ruber Study Group (IRGS), "Natural Rubber statistics 2011," Malaysia Rubber Board, 2011, http://www.lgm .gov.my/nrstat/nrstats.pdf.

[5] R. I. Hutagalung, Use of Carbohydrate Residues in Malaysia, Department of Animal Sciences, University Pertanian Malaysia, Serdang, Selangor, Malaysia, 2003.

[6] P. Tekasakul and S. Tekasakul, "Environmental problems related to natural Rubber production in Thailand," Journal of Aerosol Research, vol. 21, pp. 122-129, 2006.

[7] N. Rungruang and S. Babel, “Treatment of natural rubber processing wastewater by combination of ozonation and activated 
sludge process," in Proceedings of the International Conference on Environmental Research and Technology (ICERT '08), pp. 259-263, Parkroyal Penang, Malaysia, 2008.

[8] S. Chaiprapat and S. Sdoodee, "Effects of wastewater recycling from natural rubber smoked sheet production on economic crops in southern Thailand," Resources, Conservation and Recycling, vol. 51, no. 3, pp. 577-590, 2007.

[9] K. Vijayaraghavan, D. Ahmad, and A. Y. Ahmad Yazid, "Electrolytic treatment of latex wastewater," Desalination, vol. 219, no. 1-3, pp. 214-221, 2008.

[10] E. T. Chua and L. R. Garces, "Waste Management in the Coastal Areas of the ASEAN Region: roles of goverments, banking institutions, donor agencies, private sector and communities," The World Fish Center, pp. 117-126, 1992.

[11] A. Guha, Environmental Constraints of Pacific Rim Agriculture, United States Department of Agriculture (USDA) and the Centre of Agricultural Policy Studies, Massey University, Palmerston North, New Zealand.

[12] P. E. Bacon, "Nitrogen fertilization in the environment," CRS Press, 1995.

[13] P. S. Choo, I. Ismail, and H. Rosly, The West Coast of Peninsular Malaysia, Fisheries Research Institute, Ministry of Agriculture, Penang, Malaysia, 2003.

[14] Department of Environment, Malaysia, "Environmental quality (Sewage and Industrial Effluent) Regulation 1979, Third schedule environmental quality act, 1974," 2011, http://www .doe.gov.my/portal/legislation-actsregulation-order/.

[15] J. K. Edzwald, "Coagulation in drinking water treatment: particles, organics and coagulants," Water Science and Technology, vol. 27, no. 11, pp. 21-35, 1993.

[16] M. Kang, T. Kamei, and Y. Magara, "Comparing polyaluminum chloride and ferric chloride for antimony removal," Water Research, vol. 37, no. 17, pp. 4171-4179, 2003.

[17] G. Ali, G. El-Taweel, and M. A. Ali, "The cytotoxicity and antimicrobial efficiency of Moringa oleifera seeds extracts," International Journal of Environmental Studies, no. 61, pp. 669-708, 2004.

[18] J. Beltran-Heredia, J. Sanchez-Martin, A. Munoz-Serrano, and J. A Peres, "Towards overcoming TOC increase in wastewater treated with Moringa oleifera seed extract," Chemical Engineering Journal, vol. 188, pp. 40-46, 2012.

[19] A. Olsen, "Low technology water purification by bentonite clay and Moringa oleifera seed flocculation as performed in sudanese villages: effects on Schistosoma mansoni cercariae," Water Research, vol. 21, no. 5, pp. 517-522, 1987.

[20] S. A. Muyibi and L. M. Evison, "Optimizing physical parameters affecting coagulation of turbid water with Moringa oleifera seeds," Water Research, vol. 29, no. 12, pp. 2689-2695, 1995.

[21] S. Katayon, M. J. M. M. Noor, M. Asma et al., "Effects of storage conditions of Moringa oleifera seeds on its performance in coagulation," Bioresource Technology, vol. 97, no. 13, pp. 1455-1460, 2006.

[22] A. Diaz, N. Rincon, A. Escorihuela, N. Fernandez, E. Chacin, and C. F. Forster, "A preliminary evaluation of turbidity removal by natural coagulants indigenous to Venezuela," Process Biochemistry, vol. 35, no. 3-4, pp. 391-395, 1999.

[23] J. Zhang, F. Zhang, Y. Luo, and H. Yang, "A preliminary study on cactus as coagulant in water treatment," Process Biochemistry, vol. 41, no. 3, pp. 730-733, 2006.

[24] S. M. Miller, E. J. Fugate, V. O. Craver, J. A. Smith, and J. B. Zimmerman, "Toward understanding the efficacy and mechanism of Opuntia spp. as a natural coagulant for potential application in water treatment," Environmental Science and Technology, vol. 42, no. 12, pp. 4274-4279, 2008.

[25] L. G. Torres, S. L. Carpinteyro-Urban, and M. Vaca, "Use of prosopis laevigata seed gum and opuntia ficus-indica mucilage for the treatment of municipal wastewaters by coagulationflocculation," Natural Resources, vol. 3, pp. 35-41, 2012.

[26] T. Pichler, K. Young, and N. Alcantar, "Eliminating turbidity in drinking water using the mucilage of a common cactus," Water Science and Technology, vol. 12, pp. 179-186, 2012.

[27] A. A. Ariffin, J. Bakar, C. P. Tan, R. A. Rahman, R. Karim, and C. C. Loi, "Essential fatty acids of pitaya (dragon fruit) seed oil," Food Chemistry, vol. 114, no. 2, pp. 561-564, 2009.

[28] H. P. M. Gunasena, D. K. N. G Pushpakumara, and M. Kariyawasam, Dragon Fruit-Hylocereus undatus (Haw.) Britton and Rose: Field Manual for Extension Workers, Sri Lanka Council for Agricultural Policy, Wijerama Mawatha, Colombo, Sri Lanka, 2006.

[29] Y. Mizhari and A. Nerd, "New crops as a possible solution to the troubled Israeli export market," ASHS Press, Alexandria, Va, USA, 1999.

[30] D. K. N. G. Pushpakumara, H. P. M. Gunasena, and M. Kariayawasam, "Flowering and fruiting phenology, pollination vectors and breeding system of dragon fruit (Hylocereus spp.)," Sri Lankan Journal of Agricultural Science, vol. 42, pp. 81-91, 2005.

[31] A. R. Abdullah, "Environmental pollution in Malaysia: trends and prospects," Trends in Analytical Chemistry, vol. 14, no. 5, pp. 191-198, 1995.

[32] L. S. Clesceri, A. E. Greenberg, and A. D. Eaton, Standard Methods for the Examination of Water and Wastewater, American Public Health Association, American Water Works Association and Water Environment Federation, Washington, DC, USA, 20th edition, 1998.

[33] M. Yan, D. Wang, J. Yu, J. Ni, M. Edwards, and J. Qu, "Enhanced coagulation with polyaluminum chlorides: role of pH/Alkalinity and speciation," Chemosphere, vol. 71, no. 9, pp. 1665-1673, 2008.

[34] H. A. Aziz, S. Alias, M. N. Adlan, Faridah, A. H. Asaari, and M. S. Zahari, "Colour removal from landfill leachate by coagulation and flocculation processes," Bioresource Technology, vol. 98, no. 1, pp. 218-220, 2007.

[35] A. Ndabigengesere, K. Subba Narasiah, and B. G. Talbot, "Active agents and mechanism of coagulation of turbid waters using Moringa oleifera," Water Research, vol. 29, no. 2, pp. 703-710, 1995.

[36] C. Y. Yin, S. Abdul-Talib, Y. P. Lim, M. S. N. Ismail, S. N. A. Abdul-Razak, and A. M. Mohd-Mohtar, "Turbidity removal from surface water and landfill leachate using cactus opuntia," The Journal of the Institution of Engineers, Malaysia, vol. 68, pp. 61-64, 2007.

[37] K. A. Ghebremichael, K. R. Gunaratna, H. Henriksson, H. Brumer, and G. Dalhammar, "A simple purification and activity assay of the coagulant protein from Moringa oleifera seed," Water Research, vol. 39, no. 11, pp. 2338-2344, 2005. 

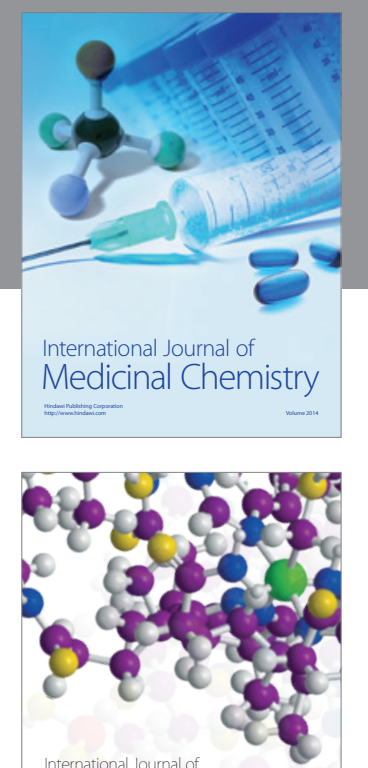

\section{Carbohydrate} Chemistry

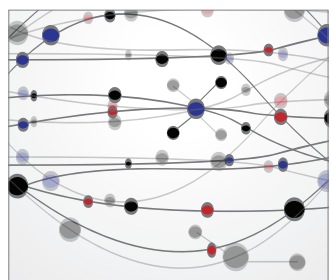

The Scientific World Journal
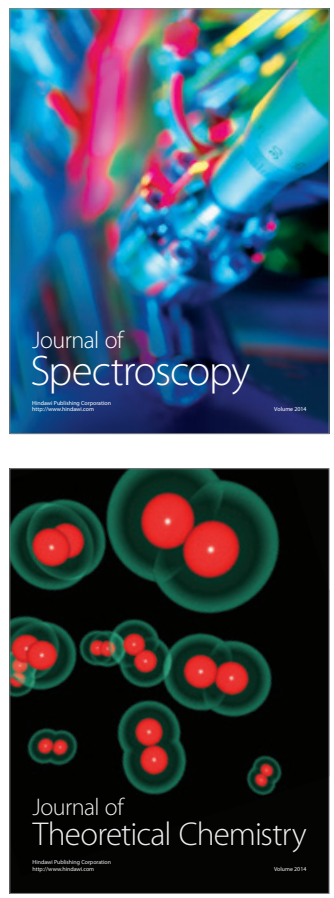
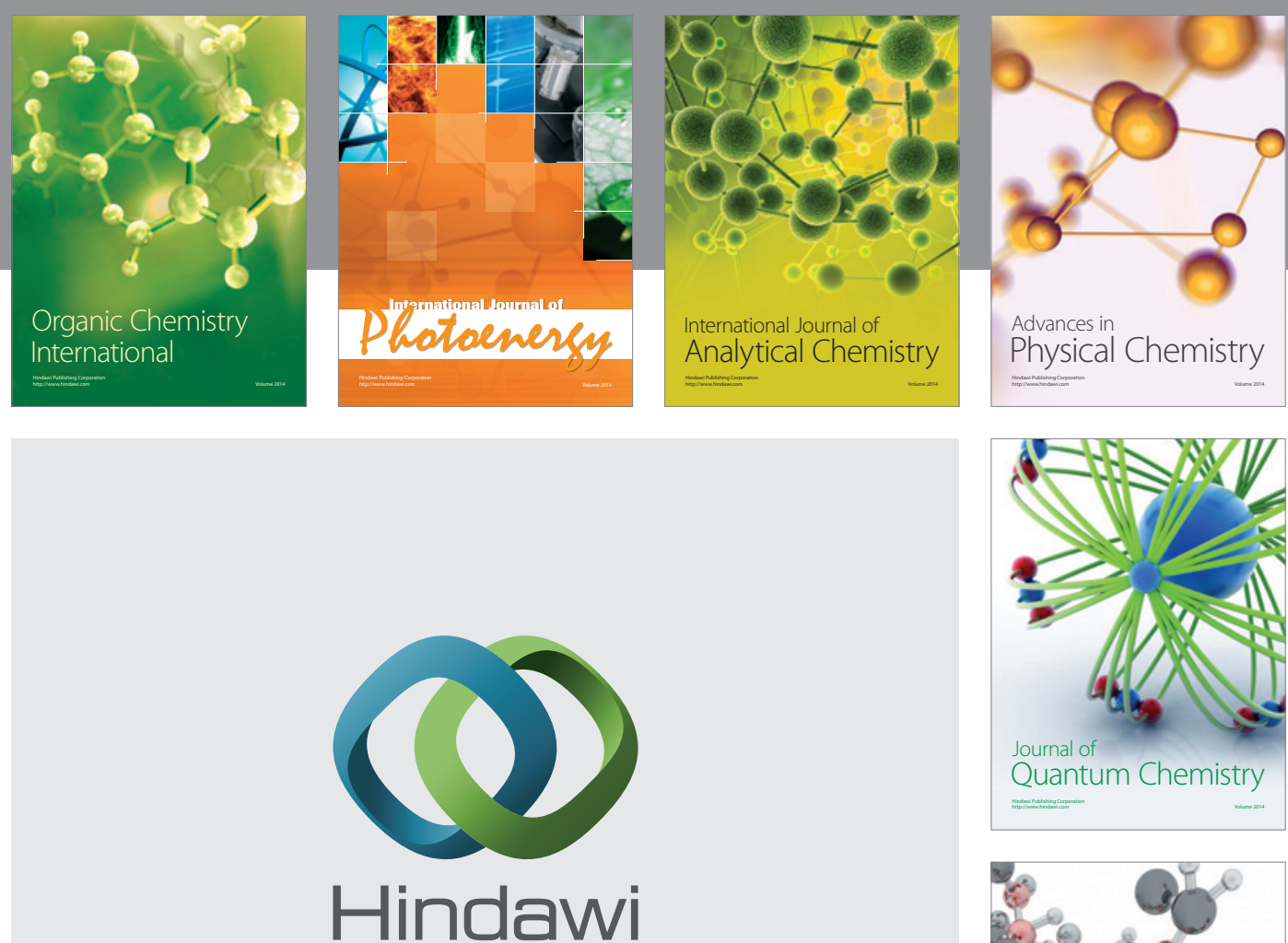

Submit your manuscripts at

http://www.hindawi.com

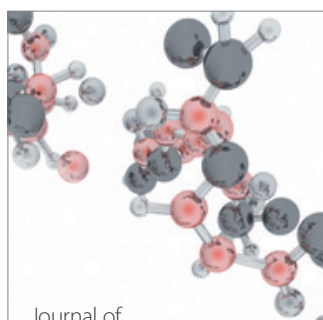

Analytical Methods

in Chemistry

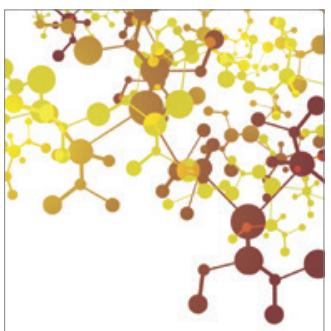

Journal of

Applied Chemistry

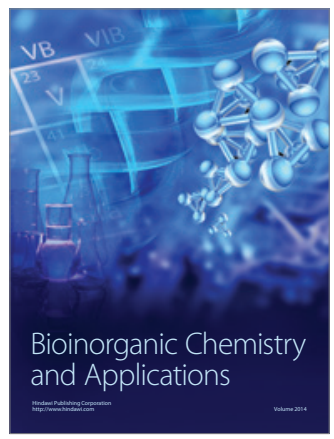

Inorganic Chemistry
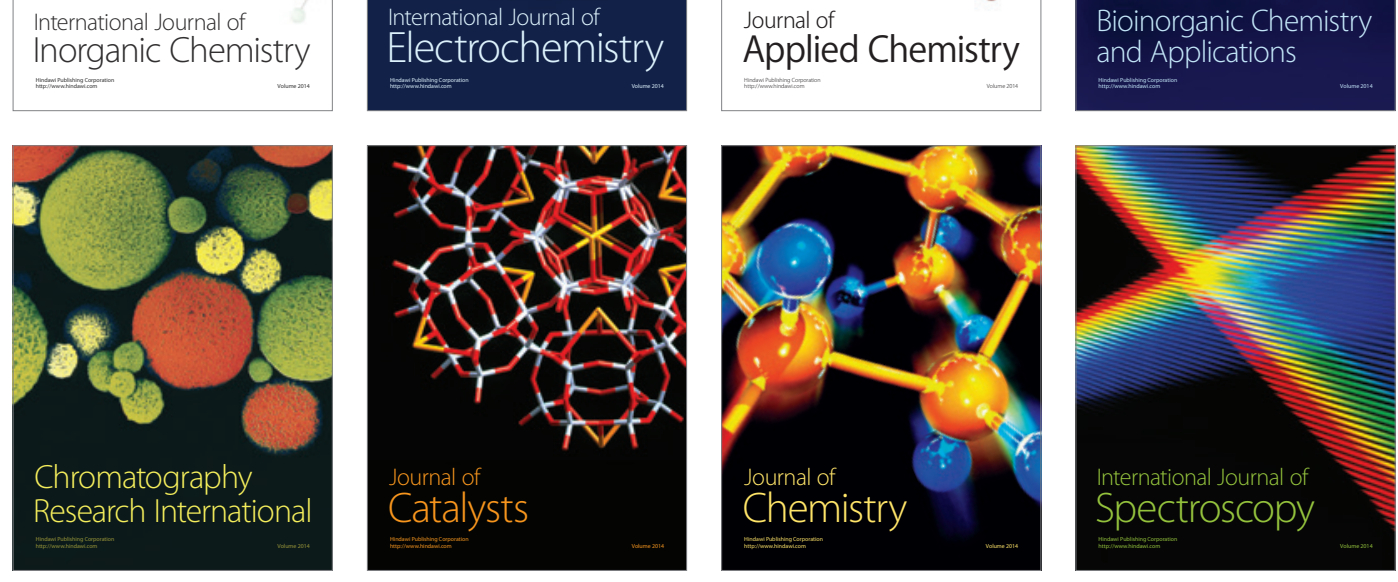